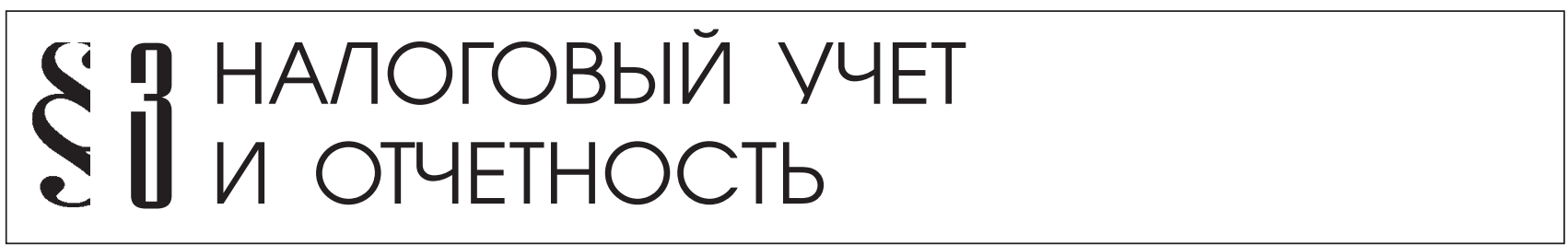

Молчанова И.В.

\title{
БУХГАЛТЕРСКИЙ УЧЕТ И НАЛОГООБЛОЖЕНИЕ БЕЗВОЗМЕЗДНОГО ПОСТУПЛЕНИЯ МАТЕРИАЛЬНЫХ ЦЕННОСТЕЙ
}

Аннотация: Согласно $n .2$ cm. 218 Гражданского кодекса РФ право собственности на имущество, может быть приобретено другим лицом на основании договора куплипродажи, мены, дарения или иной сделки об отчуждении этого имущества. В том же документе в $n .2 \mathrm{~cm} .423$ дается определение безвозмездного договора «Безвозмездным признается договор, по которому одна сторона обязуется предоставить что-либо другой стороне без получения от нее платы, то есть безвозмездно». Можем ли мы считать синонимами с точки зрения гражданского законодательства слова «дарение» и «безвозмездная передача»?

Ключевые слова: Налоги и налообложение, налогообложение, безвозмездного, материальных, иенностей, дарение, передача, активы, рыночная, стоимость

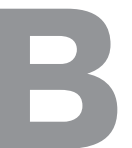

действующем законодательстве много проблемных вопросов, связанных с безвозмездной передачей имущества.

Давайте разберемся вначале, когда возможна такая безвозмездная передача?

Согласно п. 2 ст. 218 Гражданского кодекса РФ право собственности на имущество, может быть приобретено другим лицом на основании договора купли-продажи, мены, дарения или иной сделки об отчуждении этого имущества. В том же документе в п. 2 ст. 423 дается определение безвозмездного договора «Безвозмездным признается договор, по которому одна сторона обязуется предоставить что-либо другой стороне без получения от нее платы, то есть безвозмезд- но». Можем ли мы считать синонимами с точки зрения гражданского законодательства слова «дарение» и «безвозмездная передача»? Ответ на этот вопрос дается в Гражданском Кодексе РФ в п.1 ст. 572 «По договору дарения одна сторона (даритель) безвозмездно передает или обязуется передать другой стороне (одаряемому) вещь в собственность либо имущественное право (требование) к себе или к третьему лицу либо освобождает или обязуется освободить ее от имущественной обязанности перед собой или перед третьим лицом». Однако необходимо учесть положения ст. 573 ГК РФ «Отказ одаряемого принять дар». ГК РФ оставляет за одаряемым право отказаться от подарка. Отметим этот факт, он понадобится нам позже. 


\section{Налоги и налогообложение - №6(108) 2013}

На основании всего процитированного делаем вывод: Безвозмездная передача по своей сути есть дарение.

Ст. 575 ГК РФ запрещает дарение в отношениях между коммерческими организациями, за исключением обычных подарков, стоимость которых не превышает 5 минимальных размеров оплаты труда (на момент написания этой статьи 500 рублей). Значит между коммерческими организациями безвозмездная передача невозможна. Однако, по нашему мнению, есть исключение из этого правила.

В силу подпункта 11 пункта 1 статьи 251 НК РФ при определении налоговой базы по налогу на прибыль не учитывается доходы в виде имущества, полученного российской организацией безвозмездно от организации, если уставный (складочный) капитал (фонд) передающей или получающей стороны более чем на 50\% состоит из вклада (доли) соответственно получающей или передающей организации. То есть из смысла статьи понятно, что материнская компания дочерней и дочерняя материнской безвозмездно передать имущество (с том числе, деньги) может. И многочисленные Письма Минфина Р $\Phi^{1}$, и судебная практика ${ }^{2}$ эту точку зрения подтверждают. Здесь, на наш взгляд, нет противоречия. Из смысла пункта 2 статьи 1 и статьи 209 ГК РФ следует, что собственник имущества вправе по своему усмотрению совершать в отношении принадлежащего ему имущества любые

\footnotetext{
${ }^{1}$ Например, ПИСЬМО от 9 ноября 2006 г. N 03-03$04 / 1 / 736$

2 ОПРЕДЕЛЕНИЕ ВАС РФ от 10 октября 2008 г. N 13204/08 Постановление ФАС Московского округа от 06.07.2009 N КАA40/5869-09 по делу N A40-60173/08-109-186 и т.д.
}

действия, не противоречащие закону и иным правовым актам и не нарушающие права и охраняемые законом интересы других лиц, и вправе сам определять способы использования своего имущества. При наличии на то воли собственника, он вправе и безвозмездно отчуждать свое имущество в пользу других лиц без каких-либо имущественных обязательств со стороны последних. В случае, когда такое отчуждение производится в пользу дочерней компании, последняя не может реализовать свое право отказаться от дарения, так как решение принято ее учредителем и обязательно для исполнения. В этом случае нельзя ставить знак равенства между безвозмездной передачей и дарением.

Таким образом, констатируем: безвозмездная передача возможна между коммерческими организациями, находящимися между собой в отношениях материнской и дочерней компании, между некоммерческими организациями, а также с одной стороны коммерческой организацией, а с другой стороны некоммерческой организацией или физическим лицом.

\section{Бухгалтерский учет безвозмездно полученного имущества}

Учитывая безвозмездно полученное имущество, будем руководствоваться законом «О бухгалтерском учете» № 129-Ф3 от 21 ноября 1996 г., а также Положения по бухгалтерскому учету 5/01, 6/01, 9/99, и др.

Первый вопрос, который встанет перед бухгалтером, - по какой стоимости поставить полученное имущество на баланс организации? 
Пунктом 10.3 ПБУ 9/99 определено, что: « активы, полученные безвозмездно, принимаются к бухгалтерскому учету по рыночной стоимости.

Рыночная стоимость полученных безвозмездно активов определяется организацией на основе действующих на дату их принятия к бухгалтерскому учету цен на данный или аналогичный вид активов. Данные о ценах, действующих на дату принятия к бухгалтерскому учету, должны быть подтверждены документально или путем проведения экспертизы»

Понятно, что подтвердить цену «путем проведения экспертизы» означает обратиться к независимому оценщику и получить рыночную цену в предоставленном им отчете. Можно подтвердить рыночную стоимость более дешевым способом - использовать каталоги, прайс-листы и иную информацию фирм-производителей или продавцов (При этом необходимо учитывать, что под рыночными ценами понимаются рыночные цены, сложившиеся в регионе на момент исполнения сделки. Под регионом следует понимать сферу обращения продукции в данной местности, которая определяется исходя из экономической возможности покупателя приобрести товар на ближайшей по отношению к нему территории).

Однако пользуясь вторым способом, следует учитывать, что не всегда суды рассматриваются такие источники как достоверные. Так в разные годы судами не были приняты в качестве доказательства рыночной цены справка органа судебной экспертизы о цене автомобиля ${ }^{3}$, среднеста-

\footnotetext{
3 Постановление ФАС СКО от 9 июня 2003 г. N Ф081579/2003-709A.
}

тистические данные органов статистики ${ }^{4}$; информация комитетов по имуществу ${ }^{5}$; сведения торгово-промышленной палаты ${ }^{6}$ и т.д. Принимая во внимание тот факт, что эту же рыночную цену используют и для налогообложения, можно рекомендовать не экономить на услугах оценщика.

Стоимость активов, полученных безвозмездно, включаются в бухгалтерском учете (согласно п.8 ПБУ 9/99) в состав внереализационных доходов не сразу в момент их получения, а постепенно по мере списания на счета учета затрат на производство (расходов на продажу), по мере начислении амортизации. Первоначально же рыночная стоимость безвозмездно полученного имущества отражается в бухгалтерском учете на счете 98 «Доходы будущих периодов».

По учету поступления безвозмездно полученных материалов и иных запасов планом счетов предусмотрены следующие бухгалтерские проводки:

- дебет счета 10 «Материалы » кредит счета 98 «Доходы будущих периодов» - на сумму стоимости безвозмездно полученных материалов;

- дебет счета 20,26 «Расходы на производство» кредит счета 10 «Материалы» - на сумму стоимости безвозмездно полученных материалов;

- дебет счета 98-2 - кредит счета 91.1 «Прочие доходы», стоимость безвозмездно полученного имущества отражена в составе доходов.

\footnotetext{
${ }^{4}$ Постановления ФАС СЗО от 1 апреля 2002 г. N A135339/01-15, ФАС МО от 9 июля 2001 г. N КА-А40/3370-01. ${ }^{5}$ Постановление ФАС ПО от 30 ноября 2000 г. N 4403/00-14. ${ }^{6}$ Постановления ФАС СЗО от 12 августа 2002 г. N A56$858 / 02$; от 13 мая 2002 г. N A56-859/02.
} 
DOI: $10.7256 / 1812-8688.2013 .6 .2422$

При цитировании этой статьи сноска на dоі обязательна

\section{Налоги и налогообложение - №6(108) 2013}

Порядок отражения в учете безвозмездно полученных основных средств установлен п. 10 ПБУ 6/01. Согласно п. 29 Указаний по учету ОС первоначальной стоимостью основных средств, полученных организацией безвозмездно, признается их текущая рыночная стоимость на дату принятия к бухгалтерскому учету.

В соответствии с п. 12 ПБУ 6/01 в первоначальную стоимость имущества, полученного безвозмездно, включаются иные расходы, связанные с его получением. На величину первоначальной стоимости основных средств, полученных организацией по договору дарения (безвозмездно), формируются в течение срока полезного использования финансовые результаты организации в качестве внереализационных доходов. Рыночная стоимость полученных активов отражается по кредиту счета 98-2 в корреспонденции со счетом 08 «Вложения во внеоборотные активы». Суммы, учтенные на счете 98-2, списываются в кредит счета 91-1 по мере начисления амортизации.

Рассмотрим на примере учет безвозмездно полученных основных средств.

\section{Пример 1.}

Организация безвозмездно получила компьютер, рыночная стоимость на дату принятия к учету составила 32500 руб. Затраты организации, связанные с его модернизацией 2850 руб. без НДС. Срок полезного использования определен в 3 года. Способ начисления амортизации - линейный. Компьютер используется в деятельности организации.

В бухгалтерском учете должны быть сделаны проводки:
Д 08 - К 98-2 - 32500 руб. - отражена рыночная стоимость компьютера;

Д 08 - К 60 - 2850 руб. - отражены расходы на модернизацию компьютера;

Д 01 «Основные средства» - К 08 35350 руб. - отражено принятие компьютера в эксплуатацию;

Д 26 - К 02 «Амортизация основных средств» - 981,94 руб. (35350 руб./36 мес.) - начислена амортизация (ежемесячно начиная с месяца, следующего за месяцем принятия объекта к учету).

По мере начисления амортизации, в бухгалтерском учете формируется внереализационный доход (п. 8 ПБУ 9/99,),:

Д 98-2 - К 91-1 - 902,78 руб.(3250 руб./ 36 мес.) - признан внереализационный доход.

\section{Налогообложение безвозмездно полученного имущества}

\section{Налог на добавленную стоимость}

При безвозмездной передаче имущества передающая сторона будет уплачивать НДС в бюджет, однако получатель предъявить его к зачету в бюджет не вправе (письмо Минфина России от 21 марта 2006 г. № 03-04-11/60).

\section{Налог на прибыль}

В налоговом учете стоимость безвозмездно полученного имущества (работ, услуг) или имущественных прав по общему правилу, установленному п. 8 ст. $250 \mathrm{HK}$ РФ, учитывается в полной сумме в составе внереализационных доходов в момент фактического получения имущества на дату подписания сторонами акта приемапередачи (подп. 1 п. 4 ст. 271, п. 2 ст. 273 НК РФ). 
Не учитывается при определении налоговой базы для исчисления налога на прибыль (подп. 11 п. 1 ст. 251 НК РФ) имущество, полученное организацией безвозмездно, если уставный (складочный) капитал (фонд) получающей (либо передающей) стороны более чем на $50 \%$ состоит из вклада передающей (либо получающей) организации.

При этом полученное имущество не признается доходом для целей налогообложения только в том случае, если в течение одного года со дня его получения указанное имущество (за исключением денежных средств) не передается третьим лицам.

При безвозмездном получении имущества (работ, услуг) доходы для целей налогообложения оцениваются так же, как и в бухгалтерском учете, исходя из рыночных цен,, но, с одной существенной оговоркой: не ниже рассчитываемой в соответствии с главой 25 НК РФ остаточной стоимостью - по амортизируемому имуществу и не ниже затрат на производство (приобретение) - по иному имуществу (выполненным работам, оказанным услугам). Информация о ценах должна быть подтверждена организацией-получателем имущества документально или путем проведения независимой оценки.

Так как Налоговым. Кодексом не предусмотрено порядка определения первоначальной стоимости имущества, полученного безвозмездно, то поступившие основные средства должны отражаться в налоговом учете по нулевой стоимости и не амортизироваться, а стоимость ТМЦ не принимается в расходы.

Следует отметить, что разница в правилах бухгалтерского и налогового учета приведет к появлению в бухгалтерском учете временных разниц.

Рассмотрим продолжение примера, приведенного выше. Добавим, что имущество получено от физического лица, не являющегося учредителем получателя.

Сумму НДС, предъявленную фирмой за модернизацию компьютера, организация вправе принять к вычету после принятия на учет выполненных работ при наличии счета-фактуры фирмы.

В бухгалтерском учете организации должны быть сделаны следующие записи:

Д 19 - К 60 - 513 руб. - $(2850 * 18 \%)$ отражен предъявленный НДС;

Д 68, субсчет «НДС»-К $19-513$ руб. - принят к вычету НДС;

Д 60 - К 51 - 3363 руб. - оплачены работы по модернизации компьютера;

Д 68, субсчет «Налог на прибыль» - К 77 «Отложенные налоговые обязательства» — 570 руб. (2850 руб. * 20\%) - отражено отложенное налоговое обязательство.

Для целей бухгалтерского учета оборудование, полученное безвозмездно, является прочим доходом, что отражается проводкой:

Д 09 «Отложенные налоговые активы» - К 68, субсчет «Налог на прибыль»6500 руб. (32500 руб. * 20\%).

Ежемесячно по мере начисления амортизации организация признает прочий доход в размере 902,78 руб. и уменьшение отложенного налогового актива и обязательства;

Д 68, субсчет «Налог на прибыль»К 09 «Отложенные налоговые активы»180,56 ( 902,78* 20\%) — отражено уменьшение отложенного налогового актива;

Д 77 «Отложенные налоговые обязательства» - К 68, субсчет «Налог на 
DOI: $10.7256 / 1812-8688.2013 .6 .2422$

При цитировании этой статьи сноска на dоі обязательна

\section{Налоги и налогообложение - №6(108)• 2013}

прибыль» - 15,83 руб. (570 руб. /36 мес.) - отражено уменьшение отложенного налогового обязательства;

Д 99 «Прибыли и убытки» - К 68, субсчет «Налог на прибыль» - 180,56 руб. (32500 руб. /36 мес. * 20\%) - отражено постоянное налоговое обязательство.

\section{Налог на имущцество}

Имущество полученное безвозмездно и учитываемое на балансе органи- зации является объектом налогообложения по налогу на имущество. (п.1 ст. 374 НК РФ).

В данной статье мы рассмотрели только вопросы безвозмездного поступления материальных ценностей. Много проблем возникает при безвозмездном получении финансовых вложений, имущественных прав и т.п. Однако это предмет отдельного рассмотрения. 